\title{
The Effects of Hydrogen on the Fracture Toughness Properties of Upset Welded Stainless Steel (U)
}

by

\author{
M. J. Morgan
}

Westinghouse Savannah River Company

Savannah River Site

Aiken, South Carolina 29808

DOE Contract No. DE-AC09-89SR18035

This paper was prepared in connection with work done under the above contract number with the U. S.

Department of Energy. By acceptance of this paper, the publisher and/or recipient acknowledges the U.S.

Government's right to retain a nonexclusive, royalty-free license in and to any copyright covering this paper, along with the right to reproduce and to authorize others to reproduce all or part of the copyrighted paper. 


\section{- DISCLAIMER}

This report was prepared as an account of work sponsored by an agency of the United States Government. Neither the United States Government nor any agency thereof, nor any of their employees, makes any warranty, express or implied, or assumes any legal liability or responsibility for the accuracy. completeness, or usefulness of any information, apparatus, product, or process disclosed, or represents that its use would not infringe privately owned rights. Reference herein to any specific commercial product, process, or service by trade name, trademark, manufacturer, or otherwise does not necessarily constitute or imply its endorsement, recommendation, or favoring by the United States Government or any agency thereof. The views and opinions of authors expressed herein do not necessarily state or reflect those of the United. States Government or any agency thereof.

This report has been reproduced directly from the best available copy.

Available to DOE and DOE contractors from the Office of Scientific and Technical Information. P. O. Box 62, Oak Ridge. TN 37831; prices available from (615) $576-8401$.

Available to the public from the National Technical Information Service, 'U. S. Deparment of Commerce, 5285 Port Royal Rd., Springfield, VA 22161 
Keywords:

Type 304L

Solid-State Welding

Resistance Welding

J-Integral Testing

Joining

Retention - Permanent

\section{The Effects of Hydrogen on the Fracture Toughness} Properties Of Upset Welded Stainless Steel (U)

by

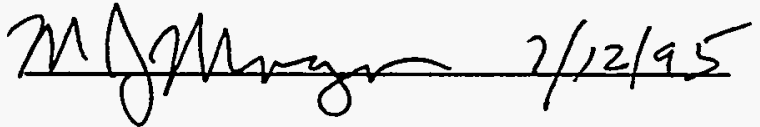

Michael J. Morgan

Materials Technology Section

Materials Compatibility and Joining Technology

\section{June 1995}

Authorized Derivative Classifier

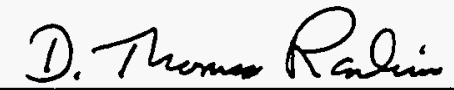

Date 
DOCUMENT: $\quad$ WSRC-TR-95-0270

TITLE: THE EFFECTS OF HYDROGEN ON THE FRACTURE TOUGHNESS PROPERTIES OF UPSET WELDED STAINLESS STEEL (U)

Approvals

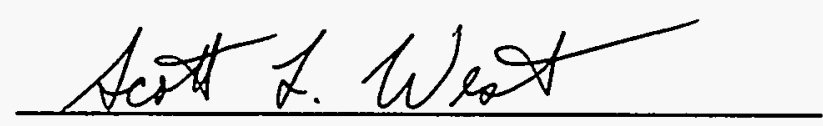

S. L. West, TECHNICAL REVIEWER MATERIALS TECHNOLOGY

D. Thom Raulin

D. Thomas Rankin, MANAGER

MATERIALS TECHNOLOGY

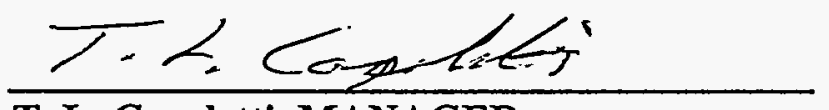

T. L. Capeletti, MANAGER

MATERIALS TECHNOLOGY
DATE: $7 / 13 / 95$

DATE: $7 / 12 / 95$

DATE:

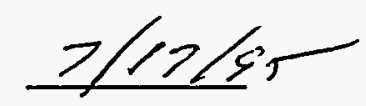


CONTENTS

SUMMARY

INTRODUCTION

EXPERIMENTAL PROCEDURE

RESULTS

DISCUSSION

CONCLUSIONS

ACKNOWLEDGMENTS

REFERENCES

FIGURES
PAGE

1

1

2

3

4

5

5

6

7 
TABLES

PAGE

\section{FIGURES}

1. ORIENTATION OF 3-POINT BEND FRACTURE TOUGHNESS SAMPLES CUT FROM 2.5 INCH DIAMETER UPSET WELDED CYLINDERS.

2. NOMINAL ASTM E813 SINGLE EDGE NotCH BEND (SENB) SPECIMEN (DIMENSIONS SHOWN ARE IN INCHES).

3. LOCATION OF NOTCH WITH RESPECT TO WELD PLANE.

4. TYPICAL MICROSTRUCTURE OF TYPE 304L STEELS NEAR EDM NOTCHIN.

5. LOAD-DISPLACEMENT RECORDS FOR UNEXPOSED SAMPLES.

6. LOAD-DISPLACEMENT RECORDS FOR HYDROGEN-EXPOSED SAMPLES.

7. J-DA CURVES FOR UNEXPOSED SAMPLES.

8. J-DA CURVES FOR HYDROGEN-EXPOSED SAMPLES.

9. TYPICAL FRACTURE APPEARANCE FOR AS-RECEIVED STEELS AND

10. DIMPLED RUPTURE FRACTURE FEATURES FOR CRACKS IN BASE METAL AND NEAR WELD INTERFACE.

11. TYPICAL DIMPLED RUPTURE FEATURES SEEN ON FRACTURES ON WELD INTERFACE. 


\title{
THE EFFECTS OF HYDROGEN ON THE FRACTURE TOUGHNESS PROPERTIES OF UPSET WELDED STAINLESS STEEL (U)
}

\author{
By \\ Michael J. Morgan
}

\section{SUMMARY}

The effects of hydrogen on the fracture toughness properties of upset welded Type 304L stainless steel were measured and compared to those measured previously for as-received and as-welded steels. The results showed that the upset welded steels had good fracture toughness properties, but values were lower than the as-received material. The fracture toughness value of the base material was 6420 in-lbs / sq. in., while the welded steels averaged 3660 in-lbs /sq. in. Hydrogen exposure lowered the fracture toughness values of the as-received steel by $43 \%$ to 3670 in-lbs /sq. in. and the welded steels by $21 \%$ to 2890 in-lbs /sq. in. The fracture morphologies of the unexposed steels showed that ductile fracture occurred by the microvoid nucleation and growth process. The size of the microvoids on the fracture surfaces of the welded steels were much smaller and more closely spaced that those found on the base material fracture surfaces. The change in the size and spacing of the microvoids indicates that the fracture toughness properties of the welded steels were lower than the base steels because of the higher concentration of microscopic precipitates on the weld plane. The welds examined thus far have been "good" welds and the presence of these precipitates was not apparent in standard "low"magnification metallographic sections of the weld planes. The results indicate that hydrogen did not weaken greatly the solid-state welds but that other inclusions or impurities present prior to welding did. Improvements in surface cleaning and preparation prior to welding should be explored as a way to improve the strength of solid-state welded joints. This report is the main deliverable toward the completion of the controlled milestone WRC02.

\section{INTRODUCTION}

Upset welding is a form of resistance welding that is applied in a variety of applications on the Savannah River Site. Resistance welds serve to seal tritium reservoirs, for attaching new fill stems to reservoirs for reclamation, and for closing the defense waste canisters (1-3). Upset resistance welds are also are being proposed for fabrication of new reservoirs and for welding caps on reclaimed reservoirs (4).

Upset welds have many attractive features when compared to fusion welds (1). One of these is the nature of the bond - upset welds achieve a solid-state metallurgical bond with virtually no melting of the steel. Diffusion and grain growth across the interface are present in good welds and are used as evidence of a strong, high-quality weld. The properties of upset welds are assumed to be similar to those of a hot-worked steel and 
therefore different than the properties associated with the solidification microstructures found in fusion welds.

The strength of upset welds has been demonstrated by pressure testing of containers, bend testing, tensile testing, and impact testing (4). Fracture toughness measurements can also be used for assessing the strength of welded joints. A sharp fatigue crack can be introduced into a test sample at or near the weld line and the resistance to cracking of the weld joint can be compared to that measured when the crack is in the base material. One of the advantages of the fracture toughness technique is that the samples can be forced to fracture on or near the weld plane and so that the effects on weld strength of the various weld parameters can be measured directly. Another advantage is that fracture toughness results can be used to predict loads at which a vessel would begin to crack or leak.

The chief purpose of this study was to measure the effects of hydrogen on the fracture toughness properties of upset welded stainless steel and to relate the fracture toughness properties to those measured in as-received and as-welded stainless steel. Although the results will be used chiefly to assess the properties of upset welded steels for the containment of hydrogen and its isotopes, they may also be useful for characterizing the properties of the large upset welds used to seal the defense waste canisters.

\section{EXPERIMENTAL PROCEDURE}

Three-point bend fracture toughness samples were cut from the walls of two $2.5^{\text {" diameter }}$ hollow cylinders that were fabricated with a large upset girth weld. Both vessels were fabricated from hollowed Type 304L stainless steel bar stock. Figure 1 shows the orientation of the samples cut from the welded cylinders. Fracture toughness samples were prepared by cutting an electric-discharge-machined (EDM) notch on their weld line so that a fatigue crack could be introduced into the welded microstructure. The nominal sample dimensions are given in Figure 3. The weld center line was identified by first using an oxalic etch and then machining the EDM notch as close as possible to the weld center line. Control samples for the study were fabricated by cutting samples from the welded containers but machining the notch in the base material and away from the weld line. Typical notch locations with respect to the weld plane are shown in Figure 3 and the microstructure of the as-received and welded steels are shown in Figure 4.

Fatigue cracks were introduced into the samples by cyclically loading them in three-point bending in displacement control according to the recommended practices of ASTM E399 (5). The fatigue cracks were introduced in displacement control and grown under decreasing loads in order to minimize residual stresses at the crack tip.

Some of the pre-cracked samples were then exposed to hydrogen gas at $350 \mathrm{C}$ and 10,000 psi. This exposure saturated the samples with approximately 9500 atomic parts per million and is typically used to test the susceptibility of a steel to hydrogen embrittlement (6). 
The samples were then tested in three-point bending at room temperature in air using an Instron Model 1125 Tension-Compression machine. The crosshead speed was 0.005 , in l. min. Load, load-line displacement, and crack length were monitored during the test. Crack lengths were monitored using a reversing $\mathrm{DC}$ potential drop technique by applying a $2 \mathrm{~A}$ current to the sample and monitoring the change in resistance of the sample across the notch tip as the crack grew. Resistance measurements were normalized with respect to resistance measurements made in a location on the sample that was not affected by crack growth. In this way, small temperature fluctuations during the test did not affect the resistance and crack length measurements. The method of Johnson (7) was used to calculate crack length from the resistance change. Fracture toughness data were obtained using the J-integral procedures of ASTM E813-89 by calculating the energy input to the samples from the area under the load-displacement records up to and beyond crack initiation (5).

\section{RESULTS}

Typical load-displacement records for the as-received and as-welded samples are shown in Figure 5. Although the data are typical for high-toughness austenitic stainless steel, the welded samples exhibited a sharper drop-off in load with increasing displacement after maximum load than the as-received samples. This indicated that crack propagation was somewhat easier in the welded steels. Hydrogen-charged samples had similar loaddisplacement behavior, Figure 6 . In this case, both the base material samples and the welded samples exhibited the sharp drop in load after maximum load.

The J-integral fracture toughness data were calculated from the load-displacement records and the crack length measurements. Typical J-da plots for the steels are shown in Figures $7-10$ and the fracture toughness results are summarized in Table I. The results show that although the upset welded steels had good fracture toughness properties, values were lower than the as-received material. The fracture toughness value of the base material was measured to be $6420 \mathrm{in}-\mathrm{lbs} / \mathrm{sq}$. in. on average, while the welded steels averaged $3660 \mathrm{in}-\mathrm{lbs} / \mathrm{sq}$. in.

The hydrogen-exposed steels had lower fracture toughness values than the unexposed steels. However, the base material fracture toughness value was affected more by hydrogen than the welded steels were. Hydrogen exposure lowered the fracture toughness values of the as-received steel by $43 \%$ and the welded steels by just $21 \%$.

Fracture of the unexposed steels occurred by ductile rupture. For the welded steels, some of the fatigue starter cracks were not quite on the weld interface. As some of these samples were deformed, the cracks tended to run onto the weld interface; in others the cracks tended to stay away from the interface. Thus, these measurements are really an indication of the toughness of the material at or near the weld interface. Figures 11 and 12 show the typical fracture appearances for the as-received and the welded steels. The size of the microvoids on the fracture surfaces of the welded steels were smaller and more closely spaced that those found on the base material fracture surfaces. This was 
particularly true when the cracks were right on the weld line. Figure 13 shows that many of the microvoids on the fracture surfaces of the welded steels were less than 0.5 um in diameter.

\section{DISCUSSION}

The results of this study show that the upset welded steels had good fracture toughness properties but the values were lower than the as-received material. Although the fracture toughness values of the welded steels were just $57 \%$ of the base material values, they both were within literature values for the fracture toughness properties of Type $304 \mathrm{~L}(8,9)$.

Table I Fracture Toughness Properties

$\begin{array}{cccc}\text { Sample } & \begin{array}{c}\text { Crack } \\ \text { Location }\end{array} & \begin{array}{c}\text { Charging } \\ \text { Condition }\end{array} & \begin{array}{c}\text { Fracture } \\ \text { Toughness } \\ \text { in-lbs / sq. in }\end{array} \\ 8 & \text { base mat'l } & \text { none } & 6126 \\ 08^{*} & \text { base mat'l } & \text { none } & 6716 \\ 1 & \text { on weld } & \text { none } & 3665 \\ 01^{*} & \text { on weld } & \text { none } & 4256 \\ 03^{*} & \text { on weld } & \text { none } & 3415 \\ 4 & \text { on weld } & \text { none } & 3301 \\ 9 & \text { base mat'l } & \text { H2-charged } & 3781 \\ 09^{*} & \text { base mat'1 } & \text { H2-charged } & 3549 \\ 7 & \text { on weld } & \text { H2-charged } & 2517 \\ 5 & \text { on weld } & \text { H2-charged } & 3057 \\ 07^{*} & \text { on weld } & \text { H2-charged } & 3082\end{array}$

All samples were fabricated from Type 304L stainless steel.

*The samples marked with an 0 in front of their ID \# were fabricated from a cylinder that was 2.63 " long; the others were taken from a cylinder 2.25 " long.

Hydrogen charged samples were exposed at 10000 psig and $350 \mathrm{C}$ for three weeks and were saturated with 9500 appm hydrogen. 
The toughness difference could partly be a yield strength effect. Fracture toughness tends to decrease within increasing yield strength and the yield strength in the vicinity of the welds in these steels may be slightly higher than that of the base material. However, the high concentration of microscopic precipitates on the fracture surfaces of the welded steels seems to be the main reason for the reduced fracture toughness properties.

Both as-received and welded steels fractured by the ductile rupture process, i.e., microvoid nucleation and growth. The size of the microvoids on the fracture surfaces of the welded steels were much smaller and more closely spaced that those found on the base material fracture surfaces. This indicates that the fracture toughness properties of the welded steels were lower than the base steels because of the higher concentration of microscopic precipitates served as many nucleation sites for microvoids. The microvoids did not have to grow very much under strain before they grew into a neighboring microvoid. The coalescence of the micovoids occurs at a lower strain and so a lower fracture toughness results.

The welds examined thus far have been "good" welds and the presence of these precipitates was not apparent from metallographic sections of the weld planes. The results also indicate that hydrogen did not weaken greatly the solid-state welds but that other inclusions or impurities present prior to welding did. These inclusions were not observable in standard low magnification metallographic sections. Improvements in surface cleaning and preparation prior to welding should be explored as potential ways to improve the strength of solid-state welded joints.

\section{CONCLUSIONS}

1. The measured fracture toughness values of upset welded Type 304L stainless steel were about $60 \%$ those of as-received steels but with the range expected for this steel.

2. Hydrogen-exposure lowered the fracture toughness values but the welded steels were less affected than the base material.

3. Surface preparation and cleanliness appear to be the major factors in the reduced fracture toughness properties of upset welded steels.

\section{ACKNOWLEDGMENTS}

Many people in the Materials Technology Section contributed to the success of this project. I am particularly grateful to William Kanne, Jr. for fabricating and welding the containers used as the source of the samples; Ken Imrich for designing, precracking and examining the welded fracture toughness samples; Zane Nelson for his assistance in hydrogen charging; James Morin for his help in fracture toughness testing; and, Delinda Williams for fractography. 


\section{REFERENCES}

1. Kanne, Jr., W. R., Solid State Resistance Welding: A Process With Unique Advantages For Advanced Materials (U), WSRC-MS-93-305, January 1994.

2. Eberhard, B. J. and Kelker, Jr., J. W., High Current Resistance Welding of Nuclear Waste Containers, Welding Journal, June 1982, p. 15-19.

3. West, S. L., Characterization of Type 304L Stainless Steel Solid-State Closure Welds for Radioactive Waste Containment", Microstructural Science, Vol. 22, ASM International, Materials Park, OH, 1995.

4. Kanne, Jr., W. R., Upset Welding Large Spherical Containers (U), March, 1991, WSRC-TR-91-157.

5. ASTM E399-83 and E813-89, Annual Book of ASTM Standards, ASTM, Phila., PA, 1990, vol. 3.01.

6. Caskey, Jr., G. R. Hydrogen Compatibility Handbook For Stainless Steels, June, 1983, DP-1643.

7. Johnson, H. H., Calibrating the Electric Potential Method for Studying Slow Crack Growth, Materias Research and Standards, Vol. 5, 1965, pp 442-445.'

8. Mills, W. J., Heat-To-Heat Variations in the Fracture Toughness Of Austenitic Stainless Steels, Engineering Fracture Mechanics, Vol. 30. No. 4, pp 469-492, 1988.

9. Morgan, M. J., The Effects of Tritium and Decay Helium on the Fracture Toughness Properties of Stainless Steels, SRT-MTS-93-4055, June, 1993. 


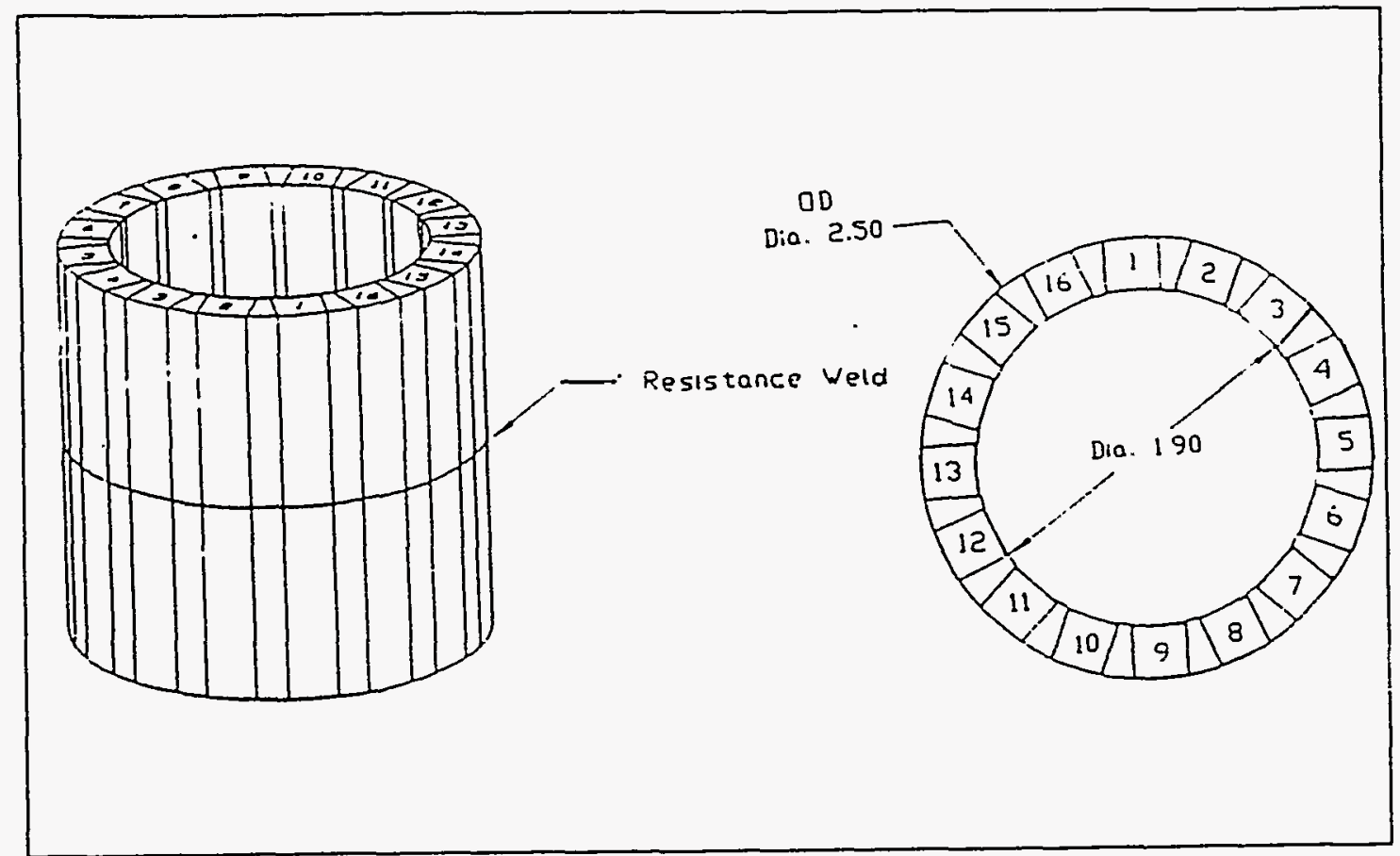

FIGURE 1. ORIENTATION OF 3-POINT BEND FRACTURE TOUGHNESS SAMPLES CUT FROM 2.5 INCH DIAMETER UPSET WELDED CYLINDERS.

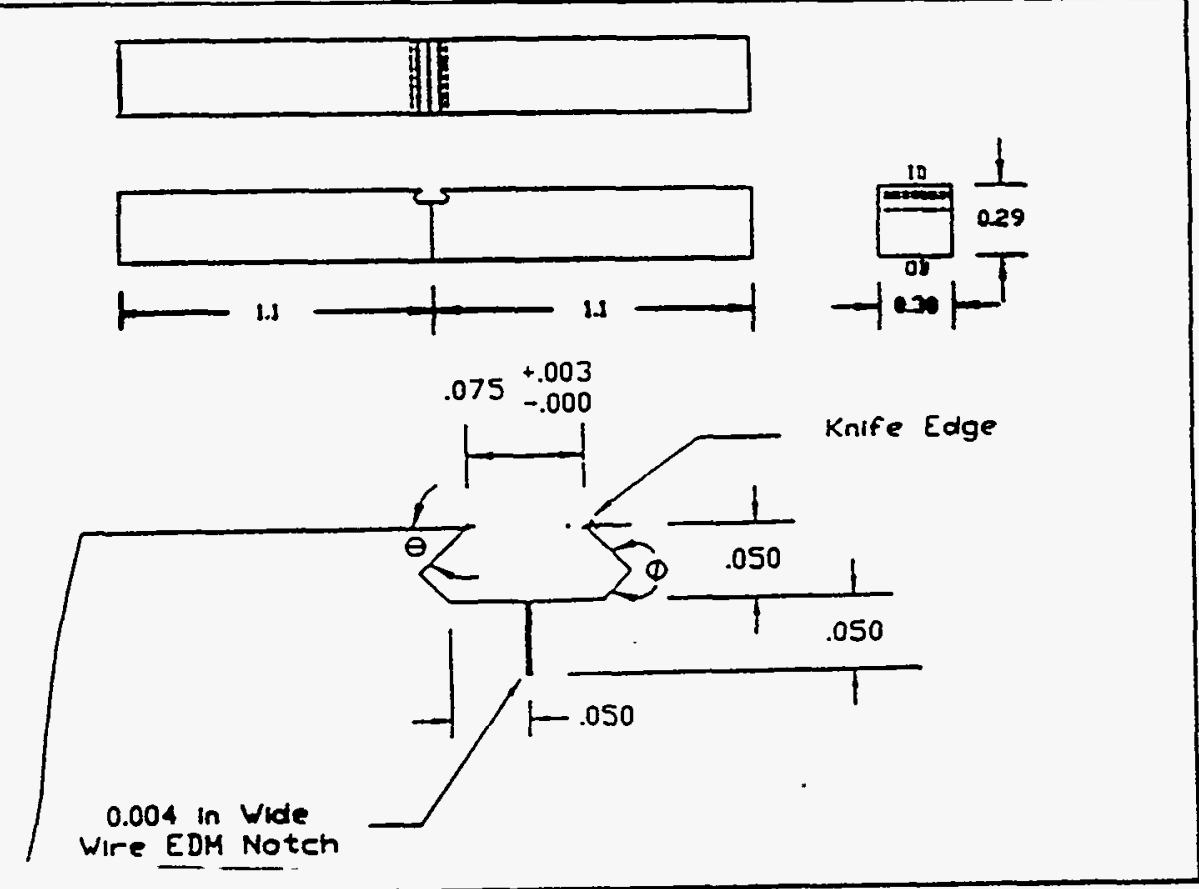

Figure 2. NOMinal ASTM E813 Single Edge Notch BEND (SENB) SPECIMEN (DIMENSIONS SHOWN ARE IN INCHES). 


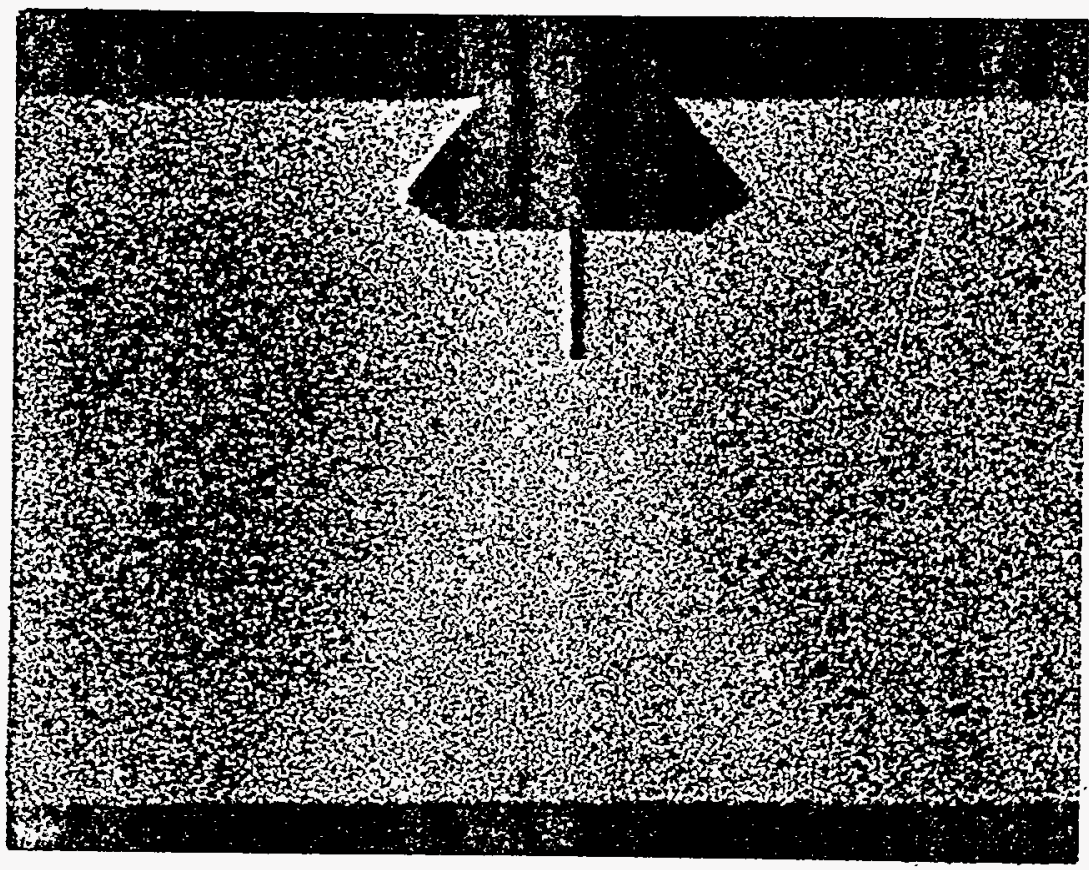

(a)

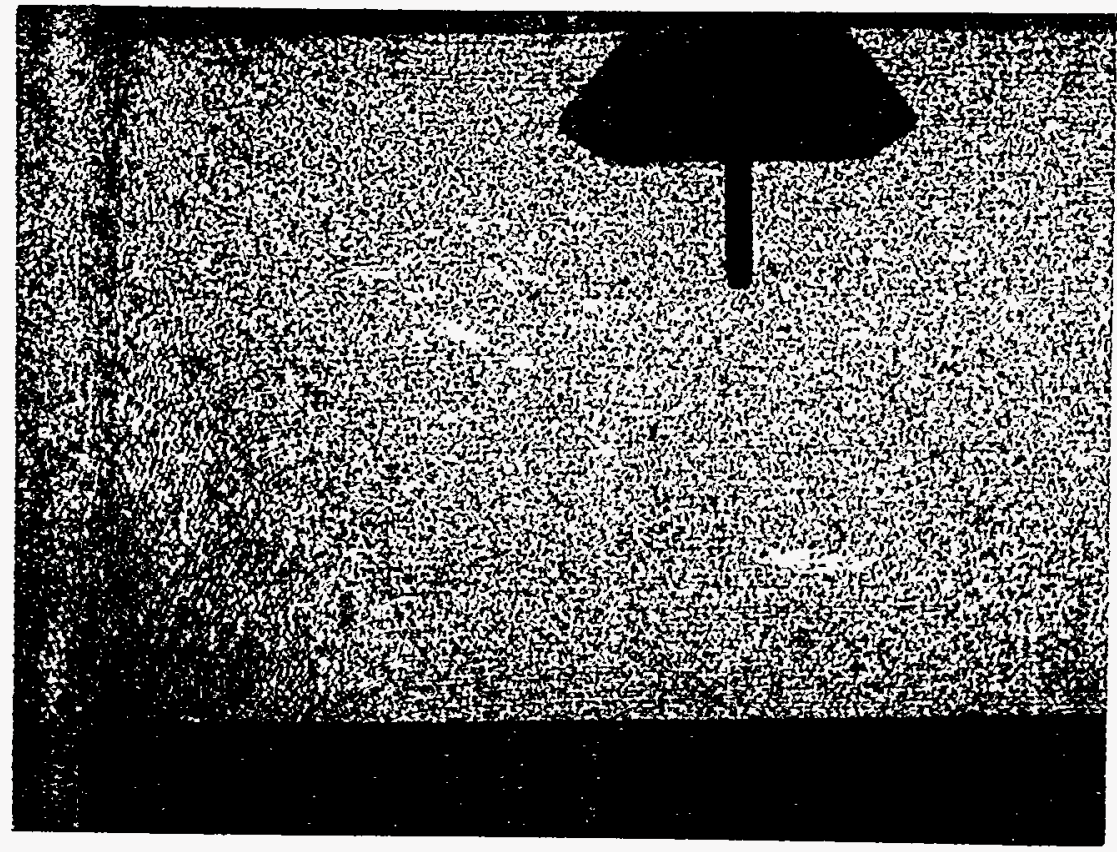

(b)

FIGURE 3. LOCATION OF NOTCH WITH RESPECT TO WELD PLANE (A) NOTCH ON WELD PlaNe; (B) NOTCH IN BASE MATERIAL (10X). 


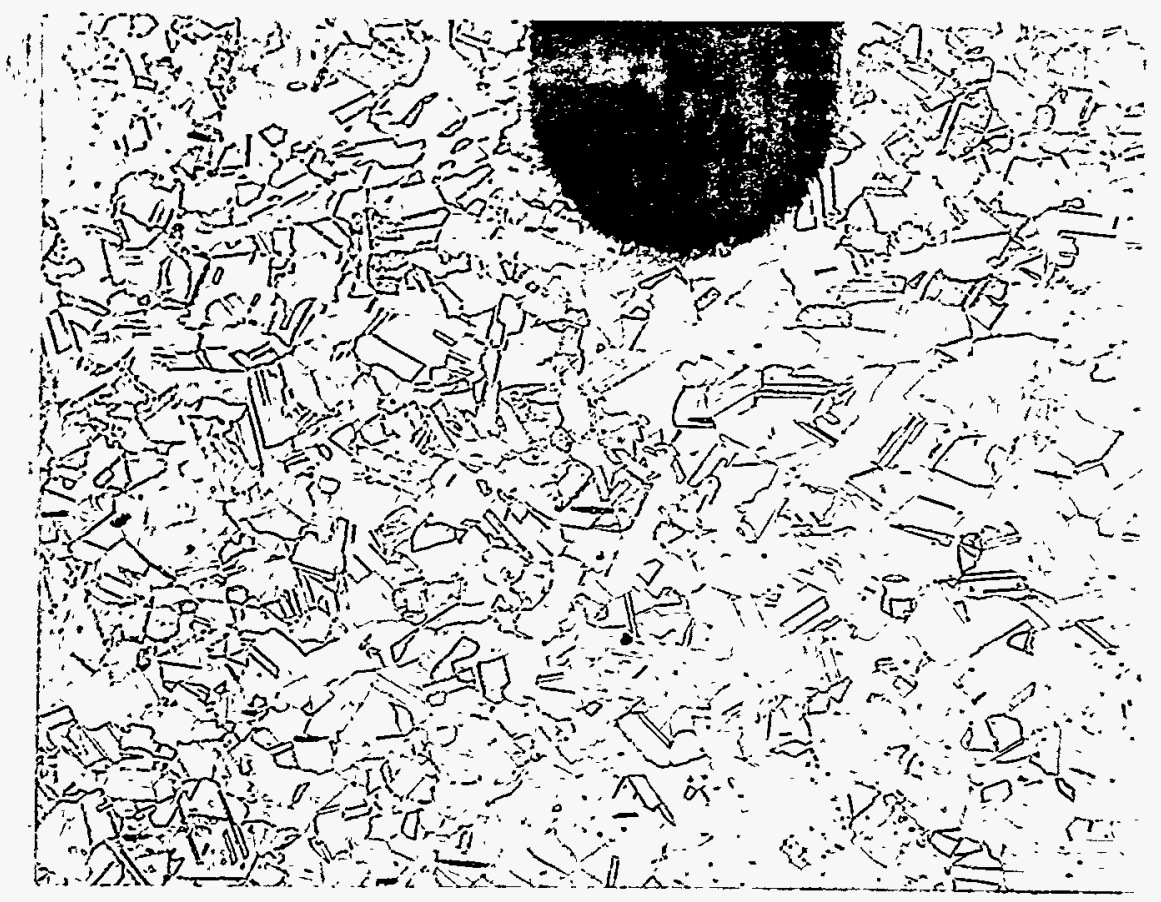

(a)

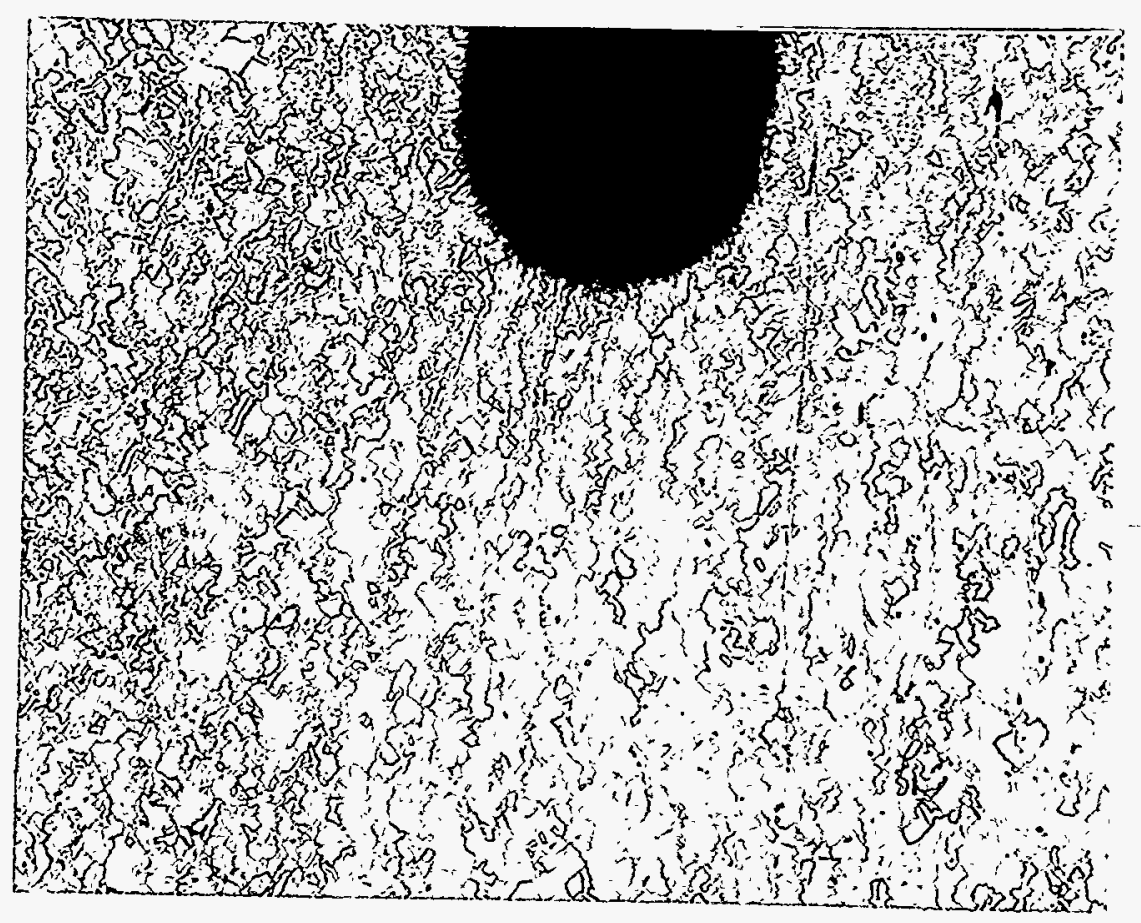

(b)

Figure 4. TYPICAL Microstructure OF TYPE 304L STEELS NEAR EDM NOTCH IN: (A) AS-RECEIVED STEEL AND (B) UPSET WELDED STEEL (200X). 


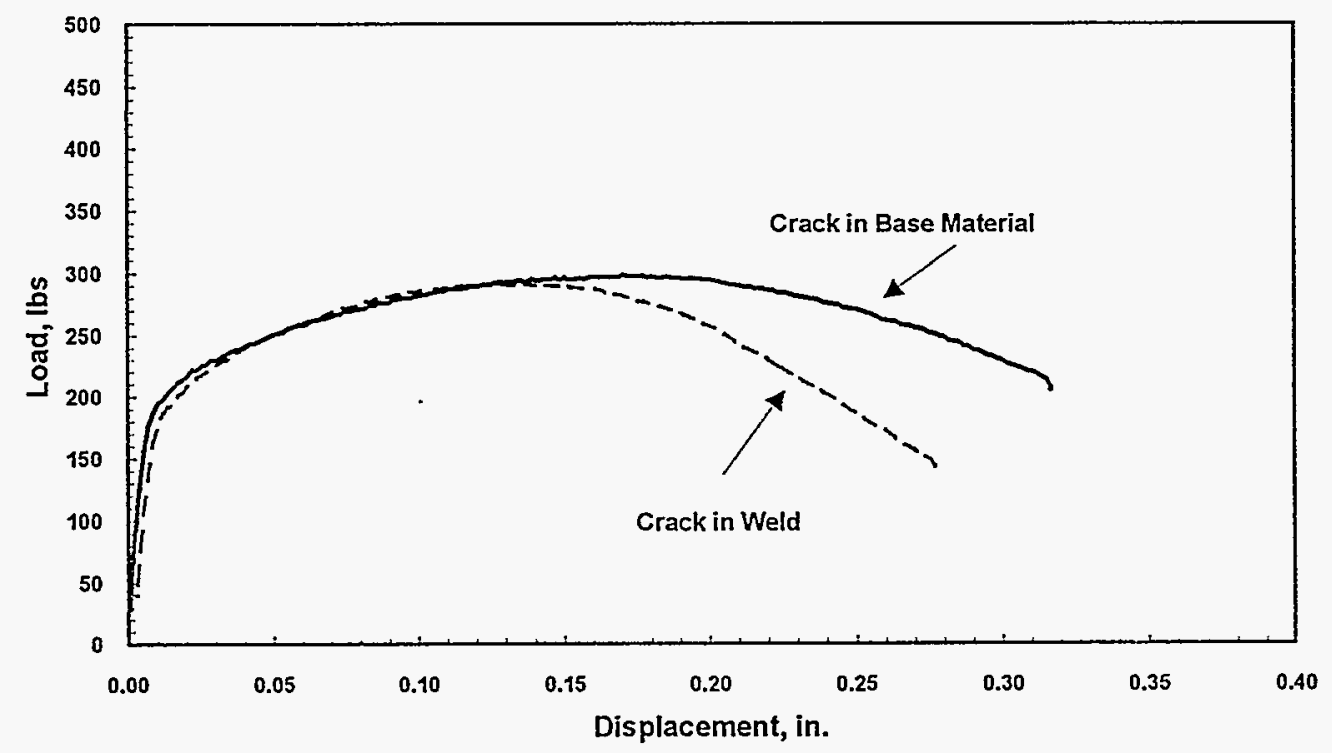

FIGURE 5. LOAD-DISPLACEMENT RECORDS FOR UNEXPOSED SAMPLES.

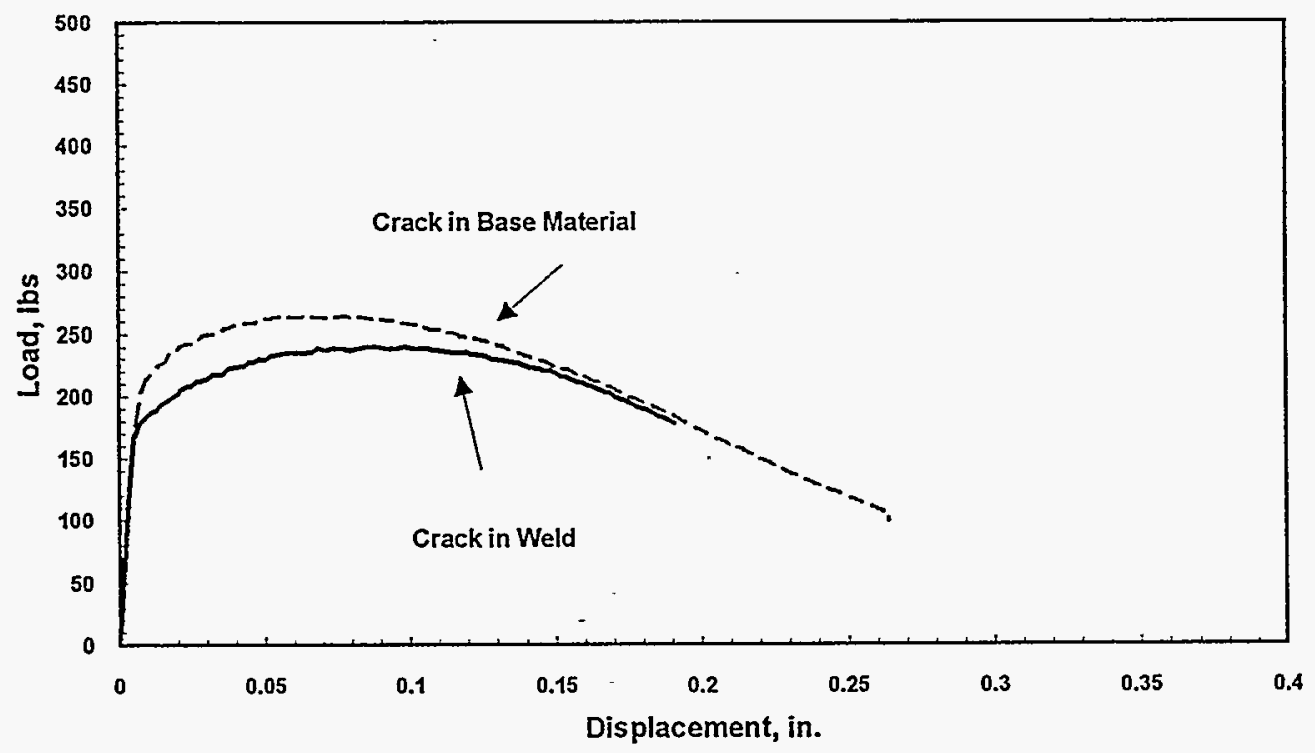

FIGURE 6. LOAD-DISPLACEMENT RECORDS FOR HYDROGEN-EXPOSED SAMPLES. 


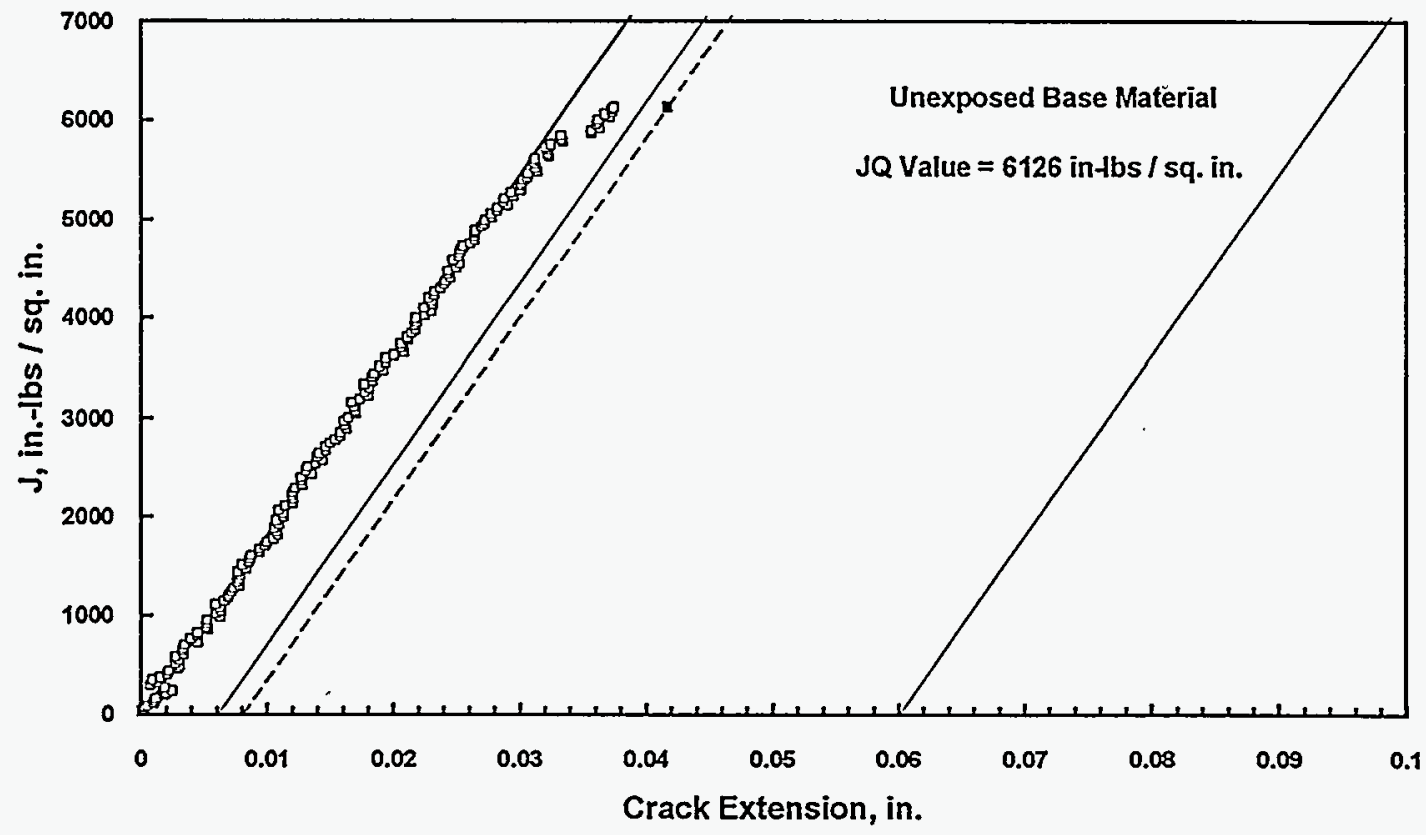

(a)

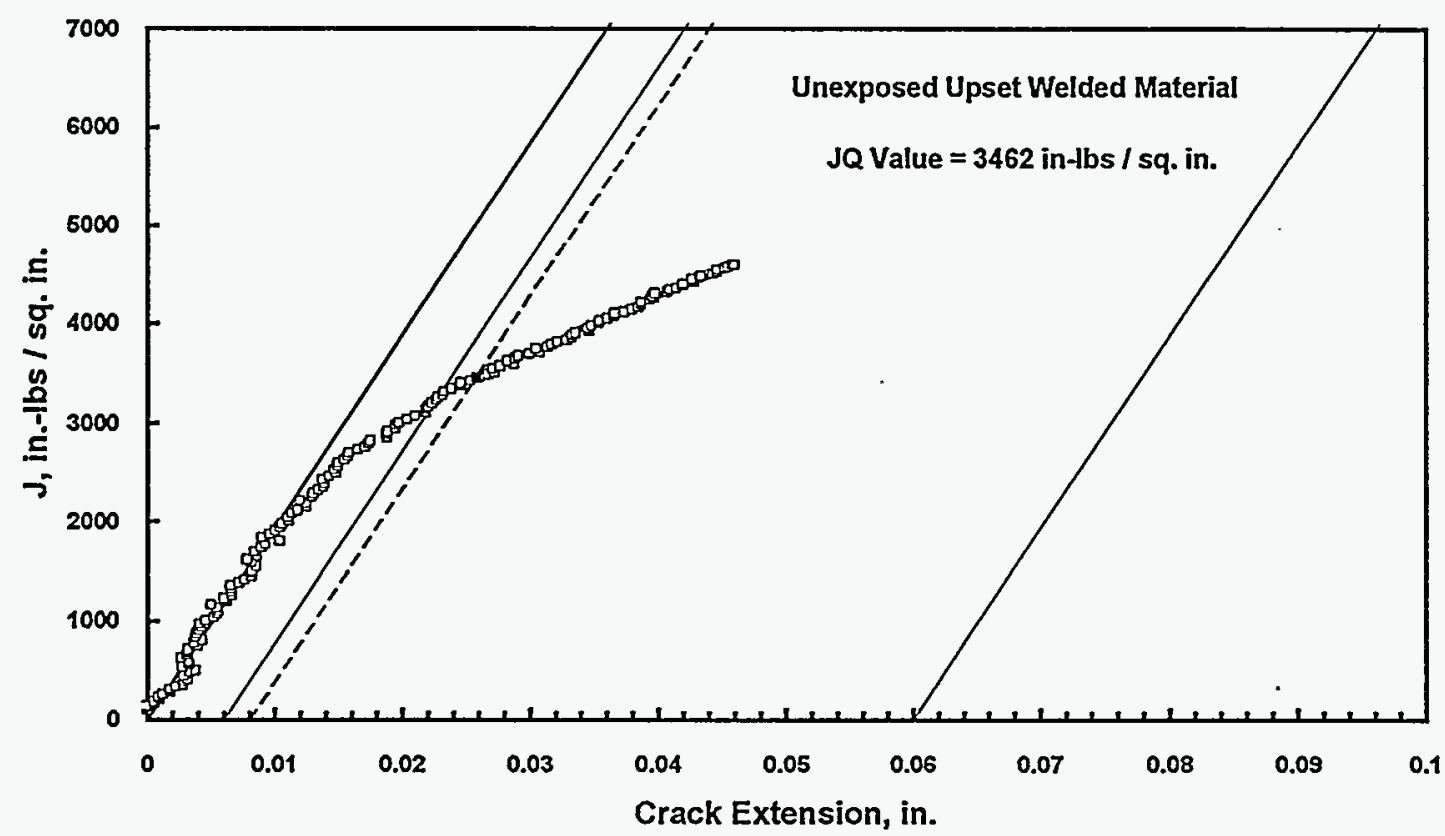

(b)

FiguRe 7. J-DA CURVES FOR UNEXPOSED SAMPLES (A) AS-RECEIVED STEEL; (B) UPSET-WELDED STEEL. 


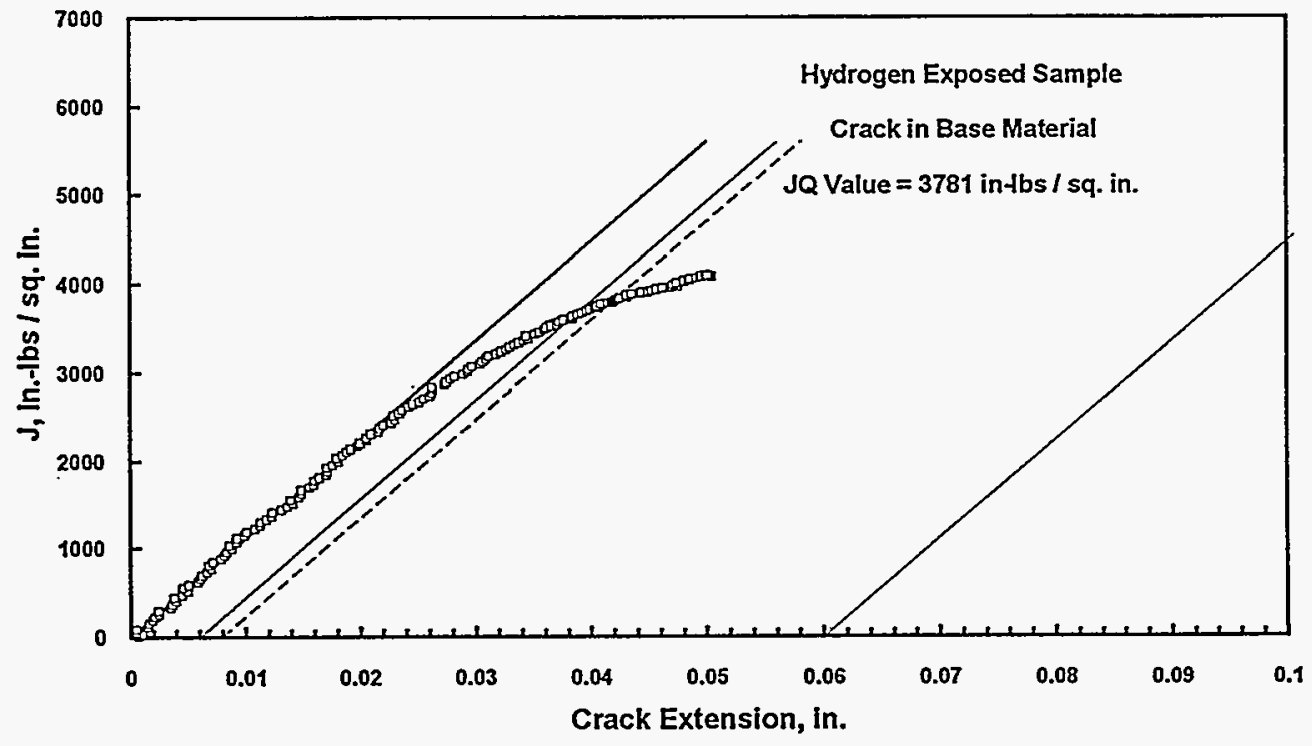

(a)

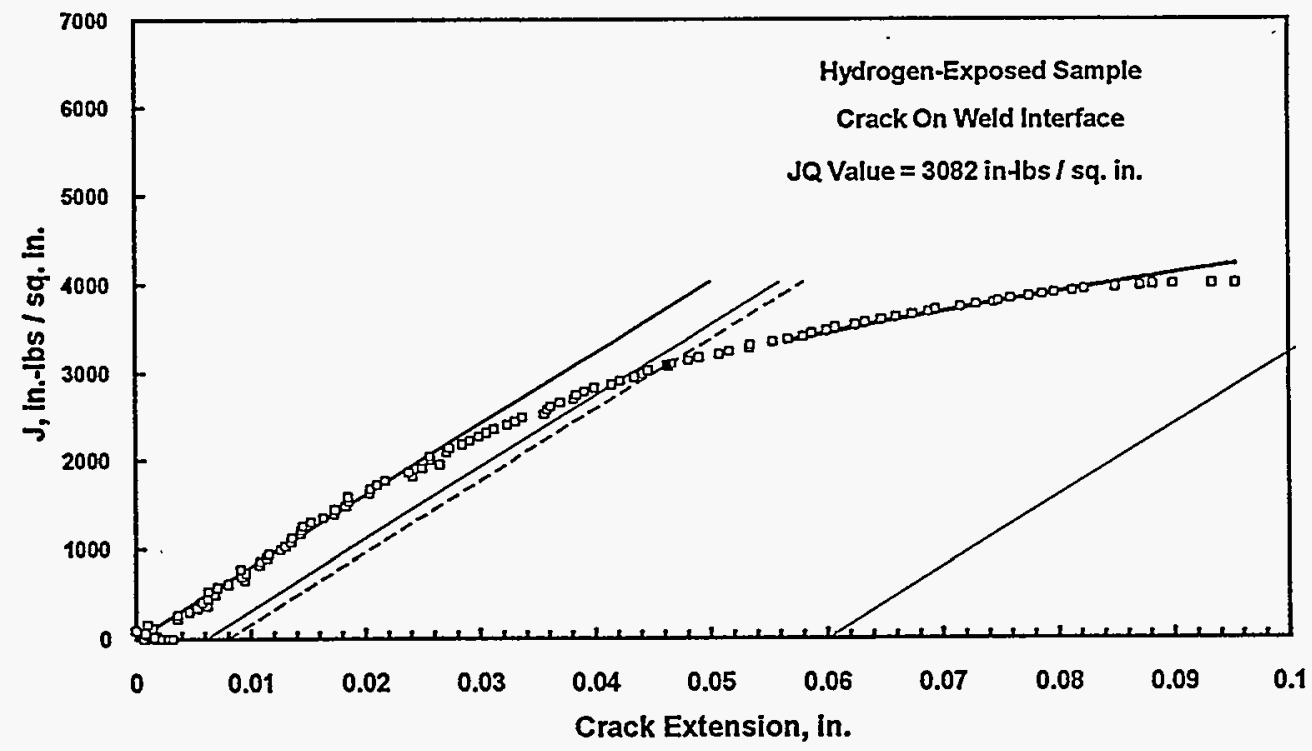

(b)

FTGURE 8. J-DA CURVES FOR HYDROGEN-EXPOSED SAMPLES TESTED IN AIR (A) ASRECEIVED STEEL; (B) UPSET-WELDED STEEL. 


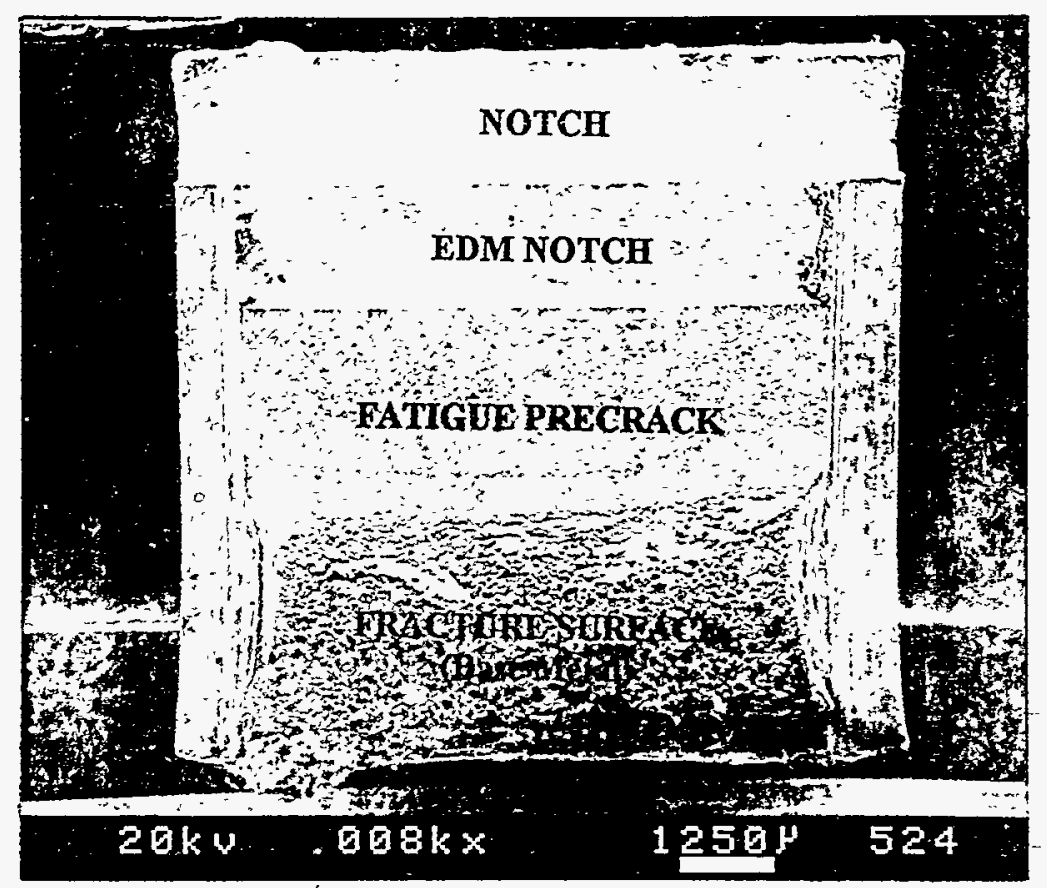

(a)

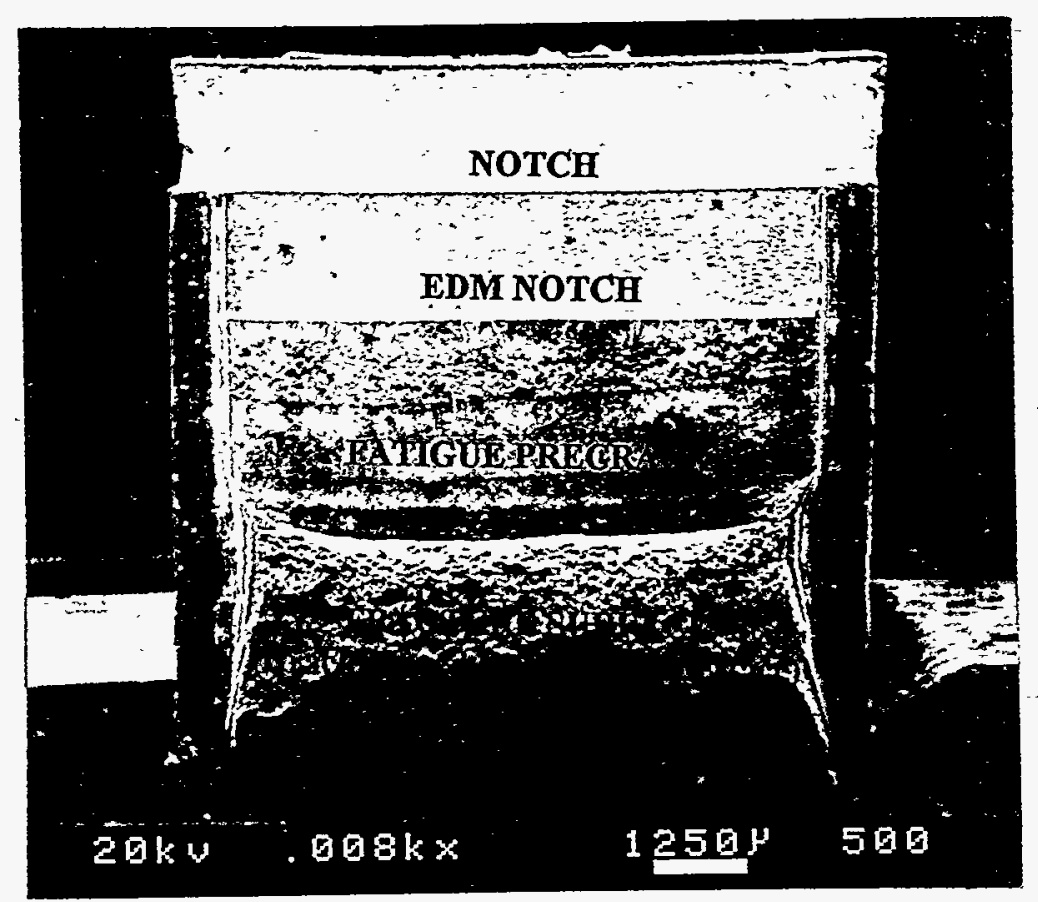

(b)

Figure 9. Typical Fracture APPearance for: (A) AS-ReCEIVEd STEel; (B) UPSET WELDED STEEL (8X). 


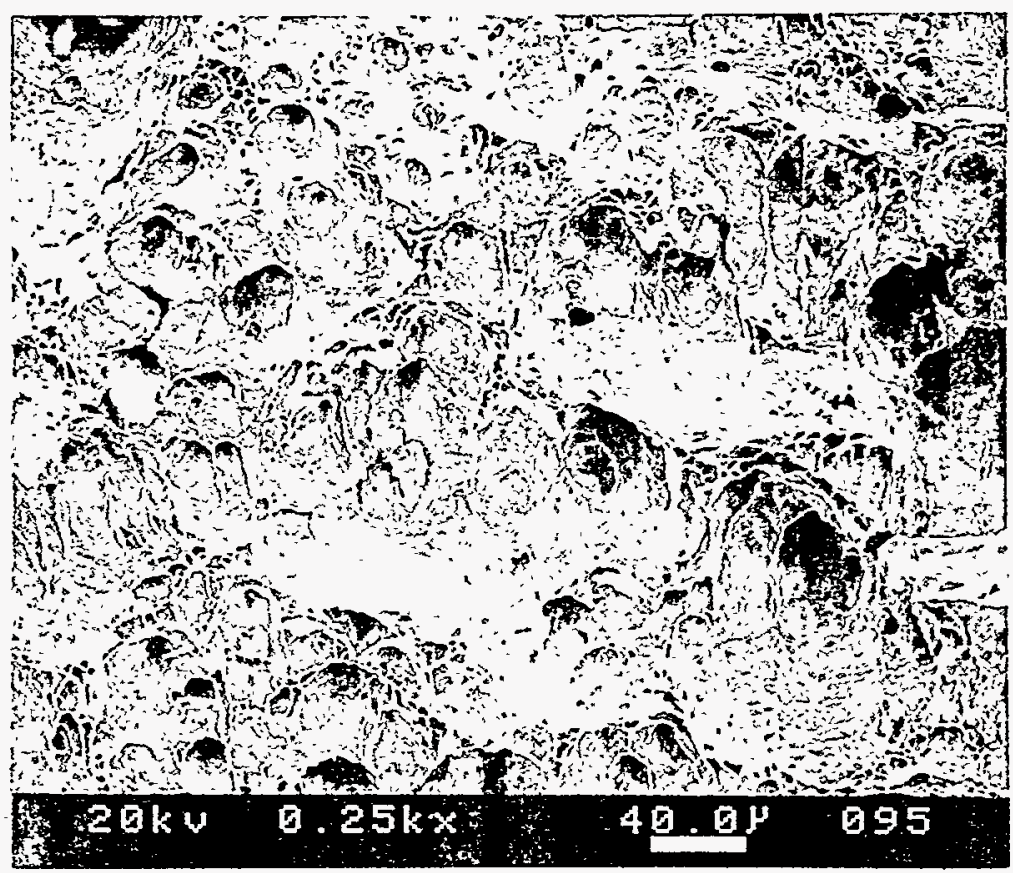

(a)

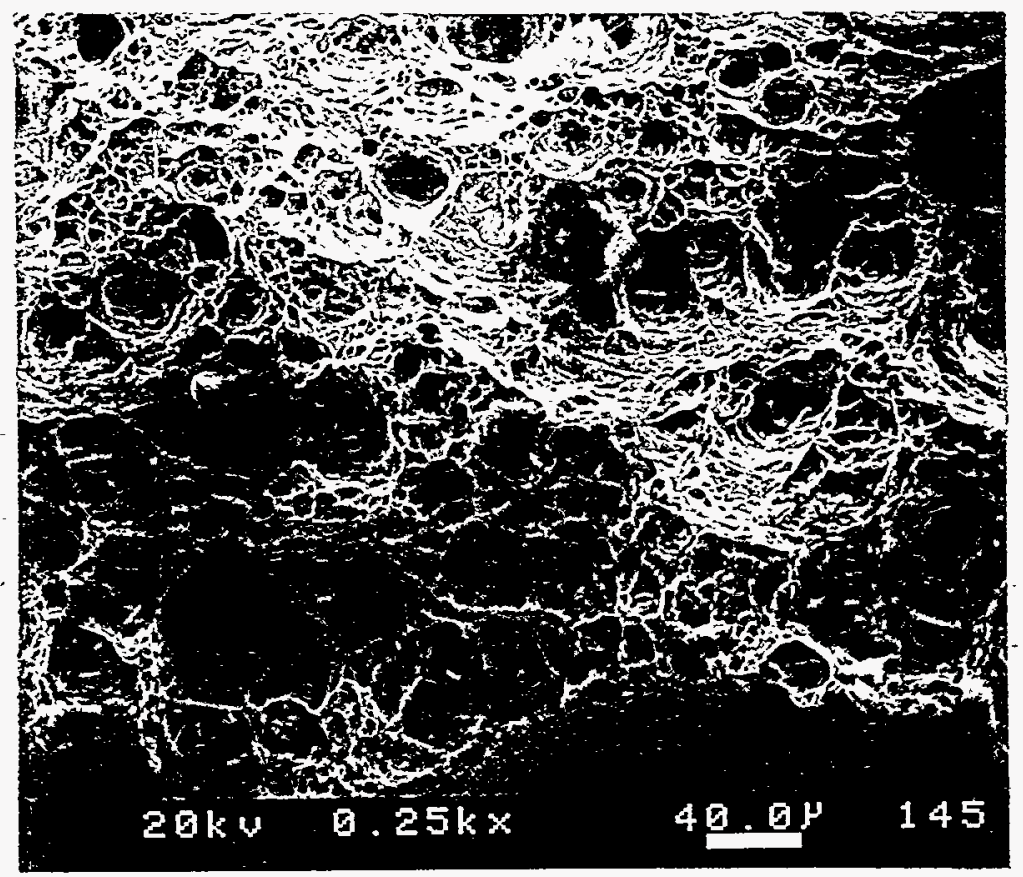

(b)

Figure 10. DIMPled Rupture Fracture Features: (A) IN Base Metal; (B) NEAR WELD INTERFACE (250X). 


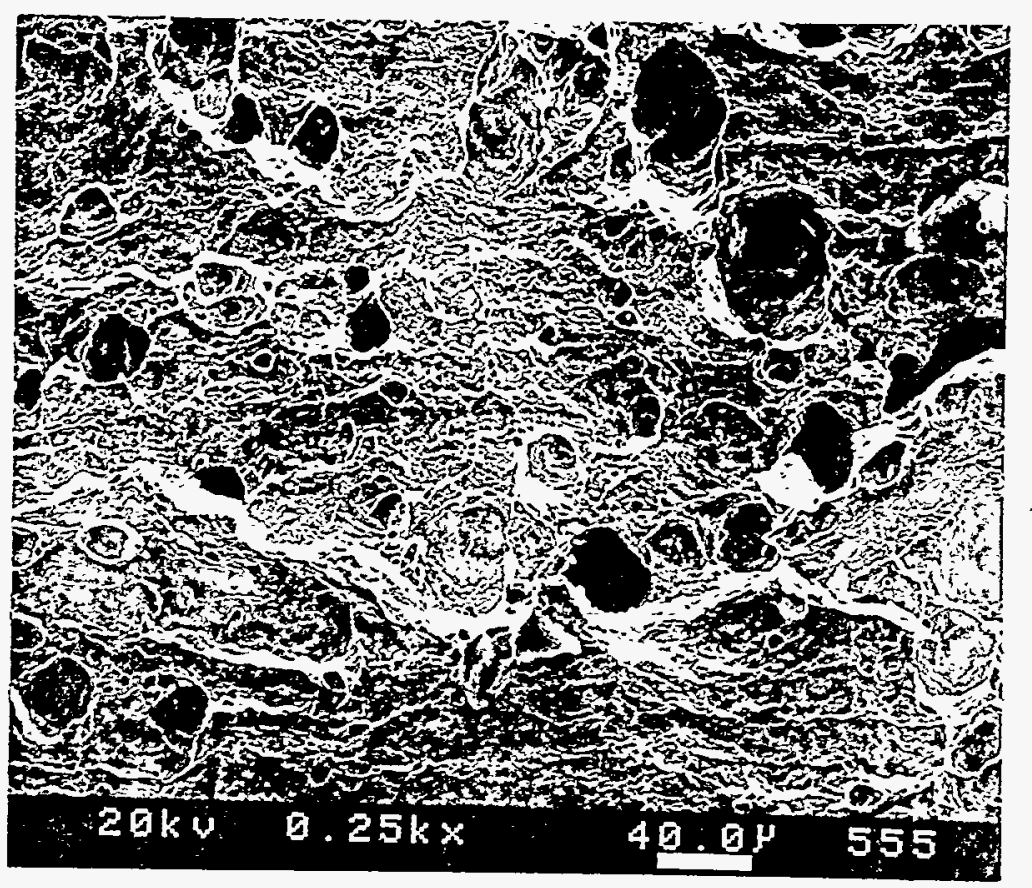

(a)

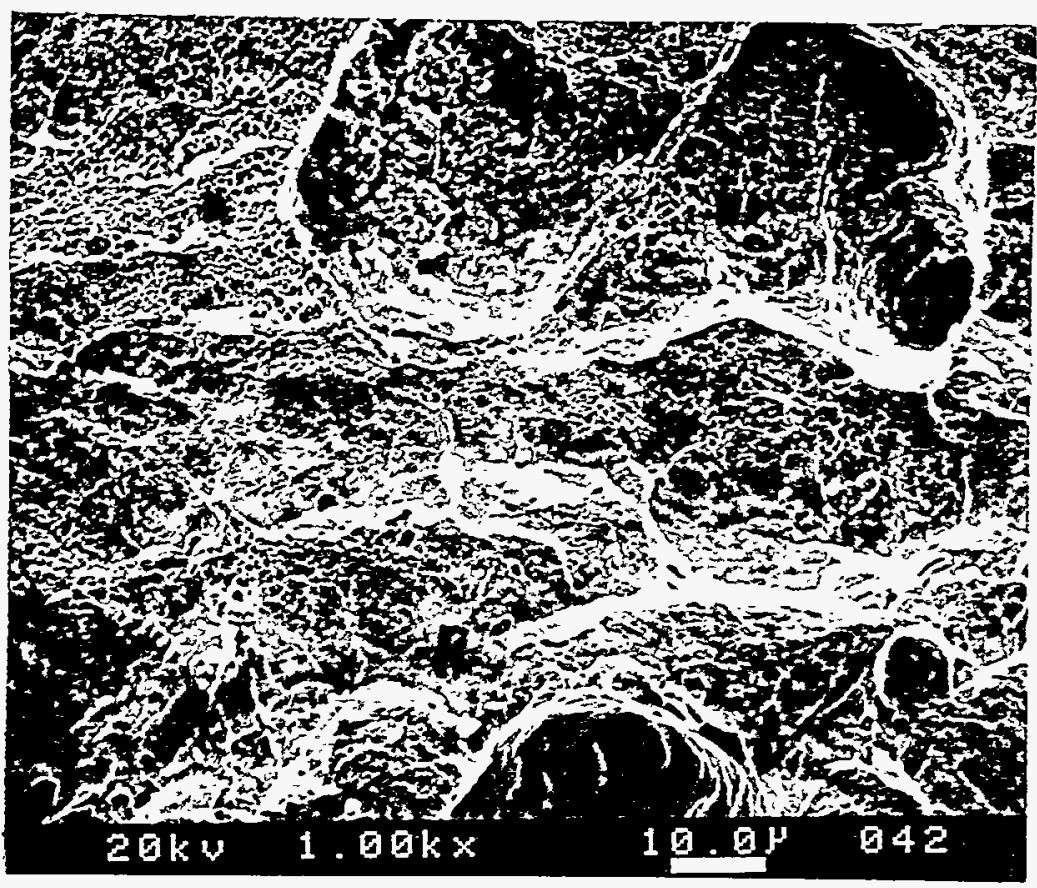

(b)

FIGURE 11. TYPICAL DIMPLED RUPTURE FEATURES SEEN ON FRACTURES ON WELD INTERFACE (A) $250 \mathrm{X}$; (B) $1000 \mathrm{X}$. 
R. J. Marek, 233-5H

J. A. Baca, DOE-AL

G. S. Herron, DOE-AL

D. J. Green, $235-\mathrm{H}$

D. L. Hayes, 235-H

T. H. Oruch, 235-H

J. D. Cohen, 773A

T. L. Capeletti, 773-41A

J. R. Knight, 773A

D. T. Rankin, 773A

N. C. Iyer, 773A

R. L. Bickford, 773A

A. F. Riechman, $773 \mathrm{~A}$

C. E. Sessions, $730 \mathrm{~A}$

M. R. Louthan, 773A

M. J. Pechersky, 773A

W. R. Kanne, Jr.773A

J. A. Morin, 773A

M. H. Tosten, 773A

E. A. Clark, $773 \mathrm{~A}$

D. Z. Nelson, 773A

S. L. West, 773A

K. J. Imrich, 773A

J. W. Congdon, 773A

E. J. Majzlik, 773A

K. A. Dunn, 773A

S. L. Robinson, SNL, CA

R. M. Gates, LANL

L. C. Michels, LANL

MTS Files (1)

SRTC Records (4) 773-A/A0261 